\title{
Development and Justification of System of Effectiveness Indicators Applied to Public Control Models in Field of Housing and Utility Sector of Tomsk Region
}

\author{
Filiushina Kristina, Trush Evgeniia, Gusakova \\ Nataliia, Dobrinina Olga \\ Department of Economics and Urban Management \\ Tomsk State University of Architecture and Building \\ Tomsk, Russia \\ kri1617@yandex.ru
}

\author{
Minaev Nikolai \\ Department of Natural Resources Economics \\ National Research Tomsk Polytechnic University \\ Department of Economics and Urban Management \\ Tomsk State University of Architecture and Building \\ Tomsk, Russia
}

\begin{abstract}
The paper describes Russian and foreign experience in elaboration of the monitoring system of budgetary expenses effectiveness. It is based on the system of indicators enabling to conduct comparative analysis within the expenditure directions, as well as it can be applied in the housing and utility sector of Tomsk Region. The system of indicators considered in the paper characterizes quantitatively measured and significant values within different directions of housing and utility sector activities. Analysis conducted in the present study resulted in formation of recommendations on effective functioning of public control in the field of housing and utility services.
\end{abstract}

Keywords - housing and utility sector; budgetary expenses; effectiveness; monitoring; system of indicators

\section{INTRODUCTION}

The housing and utility sector (HUS) has always comprised a crucial component of social sphere. One of the possible ways to increase the effectiveness of HUS performance is involvement of citizens being the main service consumers into the process of quality control of housing and utility services provision. Currently, the studies devoted to enhancing the effectiveness of budgetary expenses control and elaboration of the system of indicators are of special relevance in Russian economy, which defines the work of regional administrations and local authorities. Productivity estimation of budgetary expenses (mostly local), granted for HUS can be referred to objectives of crucial importance. The present study suggests possible solution of the mentioned problems by generalization of Russian and foreign experience including development of the system of corresponding criteria and indicators.

The principle of effective budgetary expenditure management is centered on achievement of the set management objective, i.e. provision of budgetary services of best possible quality with maximum resource saving. In order to achieve gradual positive results in effective use of budgetary funds, it is appropriate to monitor budgetary expenses. Monitoring should be performed based on the system of indicators which enable one to conduct comparative analysis within the fields of expenditures. Elaboration of the monitoring system demands to establish methodology for productivity estimation and estimation of budget funds spending effectiveness.

Theoretical justification as well as practical solution of this problem was stimulated by the target program of the Government of the Russian Federation aimed at regional finances reforming [1]. It implies providing state subsidies on a competitive basis for the regions actively transferring their work in accordance with the new principle of "result-based budgeting". Different methodologies to assess productivity of budgetary expenses were suggested within implementation of this program, also applicable to HUS.

These methodologies were regulatory documented in four constituent units of the Russian Federation: Chuvash Republic, Khabarovsk Territory, Vologda Region and Samara Region. The first steps in effectiveness assessment of budgetary expenses were undertaken in Stavropol Territory, Perm and Tver Region. As it can be seen, the level of law breaking in the field of housing and utility services is growing. Thus, in 2016 lots of violations were revealed (Fig 1).

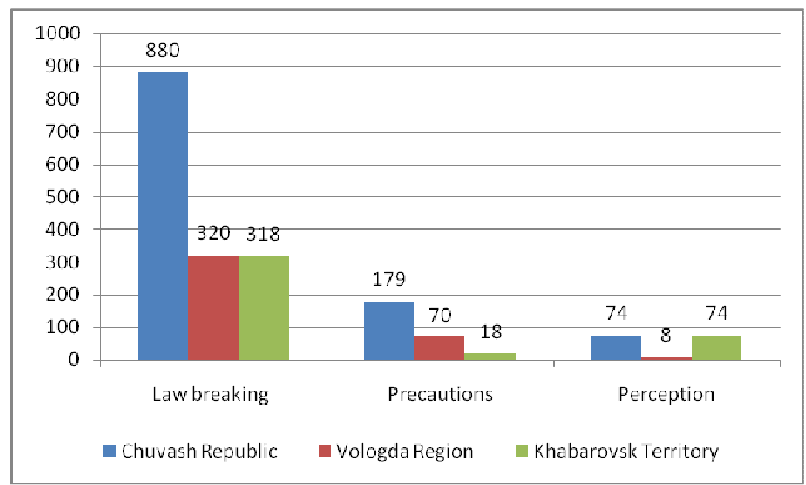

Fig. 1. Amount of law breaking cases in the field of HUS in 2016 (the numbers on the graph are given in thousands)

These numbers prove the necessity of applying methodology to assess productivity and effectiveness of budgetary funds spending. Along with that, a unified approach to assess effectiveness and practical use of the obtained results 
at this stage is still not documented [2, 3, 4]. Defining the system of indicators characterizing the work of administrations as well as applying this system is not required by law; however, it is considered to be a valuable practice all over the world.

For instance, Canada implemented Municipal program of productivity estimation aimed at increasing the effectiveness of local regulatory bodies' performance. The program also improves the standards of information disclosure and takes into account the needs of citizens. The program suggests receiving data from municipal units in order to assess productivity of nine basic public services according to 35 points scale: water supply, water disposal, solid waste disposal, road works, public transport, fire service and police. The estimate allows obtaining assessment of both economic effectiveness and public services quality. Standards of Society of Financial Service Professionals in the USA strongly recommend using the defined indicators for all the services of the public sector (quality indicators of service provision, management and financing practice). In France, regional and municipal authorities are obliged by law to comply with the definite strict standards of budget presentation, and accounting (annual provision, universality, and separation of current and capital budget, balance of budget). In Great Britain the concept of "greatest value" developed by the Counting Board was reworked into the standards of provided public services and is currently used at the national level and at the local one for everyday management of the most important public services and defining the way of their provision. The goals and reporting standards are determined annually (indicators of work presenting the largest value). Regular financial audits define the extent of compliance of public services with the people's needs, their economic effectiveness and compliance of public services quality with the definite level and demand [2].

It has to be acknowledged that the basic events of this program were not held. Legal and regulatory framework and credit and financial mechanisms of concept implementation were not developed, privatization of operating entities was not held, and approaches to competitive-based selection of management and service bodies for running state and municipal housing properties were not established. Feasibility control of fare level for housing and utility services was not provided, antitrust regulation methods during tariffs establishment were not introduced, the rates of residential rental payments depending on its quality and location were not differentiated, and the activity of HUS organizations was not demonopolized.

The concept as well as the other documents within HUS reforming do not contain even approximate estimates of social and economic consequences of transition to $100 \%$-payment of housing and public utility services. Experts considered that any significant increase of payment for housing and utilities services will lead to various negative social and economic consequences. The large part of the population will have to reduce their meal expenses and thus worsen the meal quality. Moreover, as the meal quality now leaves much to be desired, its further worsening may lead to growth of the number of deceases and healthcare expenses and progress declination at schools. The crime rate will increase, including the juvenile crime, and additional funds will be required for its control.

World experience testifies that it is not just a mood of panic. In the USA during first presidential term R. Reagan decreased granting from budget for social programs by $30 \%$, the least reduction (4\%) was connected with the subsidy housing program. However, resulting from this economy, the number of homeless people sharply increased, $40 \%$ of them were children.

Public speeches of government servants and politicians on this issue allow concluding that the issue on priorities and mechanisms of national HUS reforming are still open. Unfortunately, the data provided in the collection of Federal State Statistics Service of Russian Federation "Housing services of Russia" is not enough in order to conduct reforming. Moreover, many of the indicators provided in the mentioned document cannot be used to the full extent. For instance, the indicator of housing per capita of Russian population grows annually. But this mainly occurs due to the fact that Federal State Statistics Service changes the assessment methodology of housing services, including new objects (hotels-refuges, service rooms, etc.). Thus, the value of wear degree of the basic funds of the "Housing services" sector is 2-3 times underestimated in comparison with the information provided by specialists of Federal State Statistics Service. As a result, the real picture differs significantly from statistical indicators.

In order to analyze the state of HUS, the indicators published by Federal State Statistics Service were used. The most important factor during analysis is application of comparative assessment method and ranking of the state of HUS in the region based on integral markers and indicators.

During defining of the list of markers and indicators, it is reasonable to use statistical indicators of Tomsk Region, including (Table 1):

- annual extent of new housing supply, thou. sq. m.;

- annual extent of new housing supply, corresponding to economy class housing;

- provision of the population of the region with housing, sq. m. per people;

- index of housing availability for the population of the region.

TABLE 1. Commissioning of residential houses in Tomsk Region

\begin{tabular}{|c|c|c|c|c|}
\hline Commissioning of residential houses & 2014 & 2015 & 2016 & 2017 \\
\hline $\begin{array}{c}\text { The annual extent of new housing supply, } \\
\text { thou. sq. m. }\end{array}$ & 619.1 & 549.3 & 573.1 & 611.4 \\
\hline $\begin{array}{c}\text { The annual extent of new housing supply, } \\
\text { corresponding to economy class housing }\end{array}$ & 382.6 & 323.5 & 351.3 & 388.2 \\
\hline $\begin{array}{c}\text { Provision of the population of the region } \\
\text { with housing, sq. m. per people }\end{array}$ & 22.86 & 23.26 & 23.67 & 24.12 \\
\hline $\begin{array}{c}\text { The index of housing availability for the } \\
\text { population of the region }\end{array}$ & 3.24 & 3.53 & 3.49 & 3.46 \\
\hline
\end{tabular}

Thus, the analysis of national and foreign experience on introduction of the effectiveness assessment systems used to analyze state administrative bodies' work within the concept of "result-based budgeting" enables to highlight that the 
majority of approaches do not have an integrated basis and can be applied for solution of private objectives of territories development. Moreover, they do not allow considering many factors being crucial in modern conditions of Russia, such as optimization of financial relations mechanisms between municipalities and enterprises of HUS, social aspect in housing and utility sector, etc. Therefore existing approaches require significant methodological adaptation for effective solution of relevant objectives of public control in HUS $[3,5,6]$.

\section{LITERATURE REVIEW}

Peculiar features and management problems in HUS in modern conditions were studied by the following scientists: V.V. Buzyrev [7], P.G. Grabovoi [8], D.M. Zhukov, V.B. Zotov, A.N. Ryakhovskaya, T.V. Stepanov [2], S.B. Sivaev, Y.F. Simionov, F.G. Tagi-Zade [9], L.N. Chernyshov [10], V.Z. Chernyak, V.S. Chekalin, as well as the problems were discussed in publications of the Institute for Urban Economics, etc.

Among foreign theoretical studies in the field of housing and utility sector development special attention is paid to the works of A. Weber, K. Gassert, A. Riss, I. Redlich, and others.

Theoretical and methodological issues of formation of the system of HUS and its modernization methods were comprehensively studied by foreign scientists; among them are R. Bodwei, S. Brown, G. Wettenberg [11], E. Deutsch [12]. The works of Russian scientists should also be highlighted: V. Avdeev, N. Aminov, A. Bezlyudov, E. Blekh, V. Bogolubov, N. Vasiliev, L. Velikhov, D. Gordeev, M. Krutitskii, E. Rumyantseva.

O.A. Alekhna, V.V. Bogoliubov, I.A. Bashmakov [13], A.A. Gorbunov, O.T. Lebedev, T.V. Maleeva, E.F. Perfilova, D.G. Rodionov, A.S. Sadykov, V.G. Semenov, A.V. Talonov, E.G. Khailo, V.I. Sharapov, G.R. Yarullina and other scientists studied the development tendencies and functioning problems of regional HUS system.

Literature review on the subject of study showed that a large number of studies were held on HUS assessment and defining the problems constraining its development. Many authors come to conclusion that the basic problems are connected namely with ineffective management system. Modern institutional environment does not stimulate sustainable functioning of HUS (effective interaction of state authorities, local authorities and owners does not work). The majority of problems described by foreign and Russian scientists refer to incompliance of the institutional environment, to the peculiarities of market regulation in Russia, both in "before-the-crisis" periods (1998) A. Veber [14], R.N. Redlich [15], and nowadays I.A. Bashmakov [16], E.V. Parshuto, Y.Y. Galyamov [17].

Although different aspects of social and economic transformations in theory and practice of housing and utility sector management were considered in many scientific works, the question of public control in HUS remains unstudied.

Methodological approaches to establishment of interaction mechanisms between the citizens, public organizations and state (municipal) regulatory bodies within the process of housing and utility sector control are presented insufficiently in scientific literature.

\section{METHODOLOGY}

The given study provides generalization of Russian and foreign scientists experience and analysis of the concept and the complex system of indicators for elaboration and assessment of public control effective functioning on the example of housing and utility sector.

The idea that forms the ground of methodology applied in Tomsk region is based on performing effectiveness assessment of public control of housing and utility sector by complex indicators system. Therefore it contributes to avoiding the practice of unclear narrowly departmental bureaucratic objectives. Quantitatively measured indicators having a significant meaning for consumers of housing and utility services should be used. The basic task in this case is justification of the system of criteria and indicators to assess economic and managerial effectiveness of regional housing and utility sector performance. The given tools are meant to solve the following objectives of HUS economics:

1. Forming the basis to increase cost effectiveness and competitiveness of HUS enterprises due to broadening their financial self-dependence and at the same time responsibility for the quality of produced and rendered services; introduction of transparent and cost effective mechanisms of specialpurpose budgetary resources spending, reduction of irrational expenditures in the cost structure of basic services.

2. Providing protection of interests for HUS primary consumers, i.e. creating conditions to enhance quality and to reduce costs of rendered services by means of effective and rational mechanism of field management.

3. Receiving feedback from consumers by systematic reporting on productivity of public sector operation and conducting inquiries of the population opinion.

4. Suggesting tools for integrated information support and monitoring of effectiveness of budget funds management by regional regulatory bodies.

5. Conducting effective state and public control of enterprises and HUS regulatory bodies' activity, including control of achievement of the declared objectives on provision quality standards of rendered services, and effectiveness of using tax payer funds.

It is suggested to use sector-based methodology and information system to assess and monitor the effectiveness indicators of housing and utility sector operation and productivity of regulatory bodies' activities. Within the developed methodology, the main directions of assessment were defined, as well as priority objectives and the detailed list of final indicators characterizing quantitatively measured and significant indicators to assess effectiveness of activity within each of the directions.

In general, the principle contains 22 final indicators; their amount corresponds to the directions and priority objectives of 
activities of city administrations and municipal units in housing and utility sector.

The basic principles while selecting the final indicators are defined as follows:

1. The degree of comprehensiveness and adequacy of how the exact indicators reflect the content of goals and objectives specified while budget adoption.

2. Public significance of an indicator from the point of end consumers of HUS services, primarily population.

3. Possibility of quantitative measuring the indicators enabling to obtain comparable estimate of the completion degree of the specified objectives.

4. Preferred orientation on the indicators reflecting the estimate of end consumers, e.g. the one received from interviews with population, which is independent of the estimate of manufacturers and regulatory bodies.

5. Possibility to define and measure indicators characterizing the degree of efforts of HUS regulatory bodies in achievement of the defined objectives, e.g. over time or comparative analysis.

6. Priority of the relative indicators, reflecting simultaneously the measured estimate of quality and quantity of services and effectiveness of their rendering per ruble of budgetary and private invested money.

Along with solution of the mentioned objectives the list of acting documents of regulatory, economic, technical and information support as well as the above mentioned documents needed to be accepted were systematized.

Formation of effective management system providing quality housing and utility services requires solving the following objectives:

1) creating favorable conditions to organize activity of homeowners institutes;

2) stimulating free competitive environment on housing and utility services market;

3) creating the system of public-private control of housing and utility services quality.

The estimation of work productivity within the given objectives is assessed according to the following list of quantitatively measured indicators (Table 2).

Every group of indicators reflects the degree of completion of the given financial and economic and technical-economic indicators of public control effectiveness in housing and utility sector of Tomsk Region. It also reflects the indicators of legislative, regulatory and information aspects of activity at different levels to provide goals and objectives achievement.

Calculation of productivity indicators according to the suggested methodology can be performed directly by public control annually based on the overall reporting data of enterprises using the necessary statistical data.
TABLE 2. Indicators reflecting the effectiveness assessment of public control in the system of housing and utility sector management

\begin{tabular}{|c|c|c|c|}
\hline Objectives & Indicator description & Unit & Formula \\
\hline 1 & 2 & 3 & 4 \\
\hline \multirow{8}{*}{ 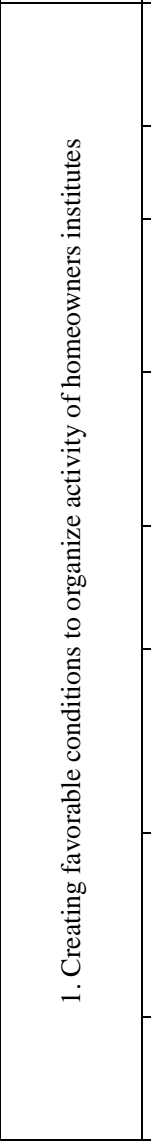 } & $\begin{array}{l}\text { The average time between the } \\
\text { decision of the meeting }\left(\mathrm{T}_{\mathrm{av}}\right) \text { and } \\
\text { beginning of activity of } \\
\text { homeowner association }(\mathrm{A})\end{array}$ & days & $\mathrm{T}_{\mathrm{av}} / \mathrm{A}$ \\
\hline & $\begin{array}{l}\text { Average expenses of owners for } \\
\text { homeowner association } \\
\text { establishment }\end{array}$ & thous.rub. & $\mathrm{E}_{\mathrm{av}}$ \\
\hline & $\begin{array}{l}\text { Consistence of events on } \\
\text { conducting public-awareness } \\
\text { campaign among population }\left(\mathrm{P}_{\mathrm{inf}}\right) \\
\text { on support of homeowner } \\
\text { association }(\mathrm{P})\end{array}$ & $\begin{array}{l}\text { unit / } \\
\text { people }\end{array}$ & $\mathrm{P}_{\text {inf }} / \mathrm{P}$ \\
\hline & $\begin{array}{l}\text { Consistence of events on } \\
\text { organizing personnel training to } \\
\text { integrate the system of self- } \\
\text { government in housing }\left(\mathrm{P}_{\text {tr }}\right) \text { out of } \\
\text { the total amount of people }(\mathrm{P})\end{array}$ & $\begin{array}{l}\text { people / } \\
\text { people }\end{array}$ & $\mathrm{P}_{\mathrm{tr}} / \mathrm{P}$ \\
\hline & $\begin{array}{l}\text { Percentage of people who received } \\
\text { certificates }\left(\mathrm{P}_{\mathrm{c}}\right) \text { out of the total } \\
\text { amount of people undergoing } \\
\text { professional training }\left(\mathrm{P}_{\mathrm{pr}}\right)\end{array}$ & $\%$ & $\left(\mathrm{P}_{\mathrm{c}} / \mathrm{P}_{\mathrm{pr}}\right) \cdot 100$ \\
\hline & $\begin{array}{l}\text { Index of the amount of guidance } \\
\text { materials and typical package of } \\
\text { documents on homeowner } \\
\text { association establishment developed } \\
\text { and transferred to the owners }\left(\mathrm{A}_{\mathrm{d}}\right) \\
\text { out of the total amount }\left(\mathrm{A}_{\mathrm{tot}}\right)\end{array}$ & & $\mathrm{A}_{\mathrm{d}} / \mathrm{A}_{\mathrm{tot}}$ \\
\hline & $\begin{array}{l}\text { Index of the amount of premises } \\
\text { transferred to homeowner } \\
\text { association at reduced-price rental } \\
\text { for personnel and contracting } \\
\text { organizations placement }\left(\mathrm{A}_{\mathrm{p}}\right) \text { out } \\
\text { of the total amount }\left(\mathrm{A}_{\mathrm{tot}}\right)\end{array}$ & & $\mathrm{A}_{\mathrm{p}} / \mathrm{A}_{\mathrm{tot}}$ \\
\hline & $\begin{array}{l}\text { The average income of } \\
\text { homeowner association obtained } \\
\text { from the use of non-residential } \\
\text { premises in houses of association }\end{array}$ & thous.rub. & $\mathrm{I}_{\mathrm{n} \text {-res }}$ \\
\hline \multirow{7}{*}{ 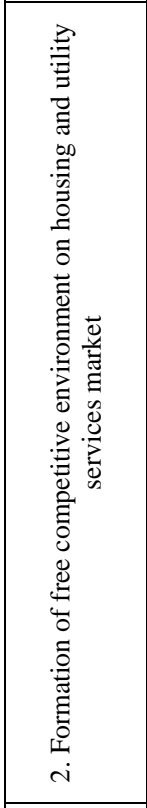 } & $\begin{array}{l}\text { The index of management } \\
\text { companies concentration }\left(\mathrm{C}_{\mathrm{mc}}\right) \text { to } \\
\text { the total population }(\mathrm{P})\end{array}$ & $\begin{array}{l}\text { unit / } \\
\text { thous.people }\end{array}$ & $\mathrm{C}_{\mathrm{mc}} / \mathrm{P}$ \\
\hline & $\begin{array}{l}\text { Percentage of management } \\
\text { companies having acting managing } \\
\text { contracts with homeowner } \\
\text { association and owners }\left(\mathrm{P}_{\mathrm{mco}}\right) \text { to the } \\
\text { total amount }\left(\mathrm{A}_{\mathrm{tot}}\right)\end{array}$ & $\%$ & $\mathrm{P}_{\mathrm{mco}} / \mathrm{A}_{\mathrm{tot}}$ \\
\hline & $\begin{array}{l}\text { Dynamics of the amount of small } \\
\text { enterprises involved in housing } \\
\text { and utility sector }\left(\mathrm{A}_{\mathrm{sme}}\right) \text { to the } \\
\text { total amount }\left(\mathrm{A}_{\mathrm{sm}}\right)\end{array}$ & $\%$ & $\left(\mathrm{~A}_{\mathrm{sme}} / \mathrm{A}_{\mathrm{sm}}\right) \cdot 100$ \\
\hline & $\begin{array}{l}\text { Dynamics of the amount of } \\
\text { legislative initiatives aimed at } \\
\text { assistance in development of small } \\
\text { enterprises in housing and utility } \\
\text { sector }\left(\mathrm{L}_{\mathrm{av}}\right) \text { to the total amount }\left(\mathrm{L}_{\mathrm{tot}}\right)\end{array}$ & $\%$ & $\left(\mathrm{~L}_{\mathrm{av}} / \mathrm{L}_{\mathrm{tot}}\right) \cdot 100$ \\
\hline & $\begin{array}{l}\text { Dynamics of the amount of } \\
\text { managing companies }\left(\mathrm{A}_{\mathrm{m}}\right) \text { to the } \\
\text { total amount }\left(\mathrm{A}_{\mathrm{tot}}\right)\end{array}$ & $\%$ & $\left(\mathrm{~A}_{\mathrm{m}} / \mathrm{A}_{\mathrm{tot}}\right) \cdot 100$ \\
\hline & $\begin{array}{l}\text { Average cost of housing and } \\
\text { utility services provided by } \\
\text { managing companies }\end{array}$ & $\begin{array}{l}\text { rub. / } \\
\text { sq.m }\end{array}$ & $\mathrm{C}_{\mathrm{av} . \mathrm{m}}$ \\
\hline & $\begin{array}{l}\text { Percentage of low-margin and } \\
\text { loss-making organizations }\left(\mathrm{O}_{\text {low }}\right) \\
\text { in their total amount }\left(\mathrm{O}_{\text {tot }}\right)\end{array}$ & $\%$ & $\left(\mathrm{O}_{\text {low }} / \mathrm{O}_{\text {tot }}\right) \cdot 100$ \\
\hline 1 & 2 & 3 & 4 \\
\hline 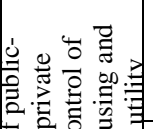 & $\begin{array}{l}\text { Percentage of managing } \\
\text { companies having certificate of } \\
\text { conformance }\left(\mathrm{K}_{\mathrm{c}}\right) \text { in their total } \\
\text { amount }\left(\mathrm{K}_{\text {tot }}\right)\end{array}$ & $\%$ & $\left(\mathrm{~K}_{\mathrm{c}} / \mathrm{K}_{\mathrm{tot}}\right) \cdot 100$ \\
\hline $\begin{array}{llll}0 & 0 & 0 & 0\end{array}$ & $\begin{array}{l}\text { Percentage of managing } \\
\text { companies whose activity was }\end{array}$ & $\%$ & $\left(\mathrm{~K}_{\text {sus }} / \mathrm{K}_{\mathrm{tot}}\right) \cdot 100$ \\
\hline
\end{tabular}




\begin{tabular}{|c|c|c|}
\hline $\begin{array}{l}\text { suspended by professional market } \\
\text { members }\left(\mathrm{K}_{\text {sus }}\right) \text { in their total } \\
\text { amount }\left(\mathrm{K}_{\mathrm{tot}}\right)\end{array}$ & & \\
\hline $\begin{array}{l}\text { Percentage of managing companies } \\
\text { included into professional } \\
\text { organizations, }\left(K_{\text {prof }}\right) \text { in their total } \\
\text { amount }\left(K_{\text {tot }}\right)\end{array}$ & $\%$ & $\left(\mathrm{~K}_{\text {prof }} / \mathrm{K}_{\mathrm{tot}}\right) \cdot 100$ \\
\hline $\begin{array}{l}\text { The index of registered } \\
\text { complaints of population } \\
\text { regarding the quality of housing } \\
\text { and utility services }\end{array}$ & & $\mathrm{P}_{\mathrm{com}}$ \\
\hline $\begin{array}{l}\text { Percentage of complaints of } \\
\text { population resulting into penal } \\
\text { sanctions of civil law character by } \\
\text { professional market members } \\
\left(\mathrm{P}_{\text {pen }}\right) \text { in their total amount }\left(\mathrm{P}_{\text {tot }}\right)\end{array}$ & $\%$ & $\left(\mathrm{P}_{\mathrm{pen}} / \mathrm{P}_{\mathrm{tot}}\right) \cdot 100$ \\
\hline $\begin{array}{l}\text { Percentage of complaints of } \\
\text { population regarding the quality } \\
\text { of housing and utility services } \\
\text { registered through public internet- } \\
\text { forums created by HUS } \\
\text { regulatory bodies }\left(\mathrm{P}_{\text {int }}\right) \text { in their } \\
\text { total amount }\left(\mathrm{P}_{\text {tot }}\right)\end{array}$ & $\%$ & $\left(\mathrm{P}_{\text {int }} / \mathrm{P}_{\text {tot }}\right) \cdot 100$ \\
\hline $\begin{array}{l}\text { Dynamics of increase (decrease) } \\
\text { of the amount of public internet- } \\
\text { forums created by HUS } \\
\text { regulatory bodies }\left(\mathrm{T}_{\text {int }}\right) \text { in their } \\
\text { total amount }\left(\mathrm{T}_{\text {tot }}\right)\end{array}$ & $\%$ & $\left(\mathrm{~T}_{\text {int }} / \mathrm{T}_{\text {tot }}\right) \cdot 100$ \\
\hline
\end{tabular}

\section{CONCLUSION}

Suggested methodology enables to perform quality assessment of work on the assumption of compliance with the actual values, e.g. with the scale in Table 3. Elaboration of indicators for the given criteria is a labor-intensive process that should involve federal and regional industry-based bodies as the system of criteria and indicators should take into account peculiar features of Tomsk Region to a maximum extent and should be differentiated accordingly [18, 19].

TABLE 3. Indicators' productivity

\begin{tabular}{|l|c|}
\hline \multicolumn{1}{|c|}{ Scale } & $\begin{array}{c}\text { Value of } \\
\text { indicators, \% }\end{array}$ \\
\hline $\begin{array}{l}\text { "High productivity" (the average value of positive growth } \\
\text { of actual values of indicators from the planned ones) }\end{array}$ & 110 \\
\hline $\begin{array}{l}\text { "Medium productivity" (the average value of growth of } \\
\text { actual values of indicators from the planned ones) }\end{array}$ & $100-110$ \\
\hline $\begin{array}{l}\text { "Low productivity" (the average value of deviation of } \\
\text { actual values of indicators from the planned ones) }\end{array}$ & $90-100$ \\
\hline $\begin{array}{l}\text { "Very low productivity" (the average value of deviation } \\
\text { of actual values of indicators from the planned ones). }\end{array}$ & Less than 90 \\
\hline
\end{tabular}

\section{Acknowledgement}

The present paper was written within the financial support of the Russian Foundation for Basic Research, project "The formation of economic and managerial models of public control in the sphere of housing and communal complex of Tomsk Region”, No. 17-12-70004 a(p), 2017.

\section{References}

[1] Opyt realizatsii programm reformirovaniya regionalnykh finansov [Experience of implementation of Program of regional finances reforming], Seminar materials, Edited by A.V. Yurin, 2003.

[2] T.V. Stepanova, Evropeiskii opyt realizatsii obschestvennogo kontrolya za rabotoi gosudarstvennoi vlasti: primer Skandinavskikh stran [European experience of arranging public control of regulatory bodies work - the example of Scandinavian countries], from http://c.a2gsecure.com/?E=WK414g\%2bscJFC\%2fH6IRkKa\%2bA\%3d\%3d-

$11 \mathrm{gGst} 5 \mathrm{pXBU} \% 3 \mathrm{~d} \& \mathrm{~s} 1=\mathrm{RU} \&, 2014$.

[3] Mirovoi opyt obschestvennogo kontrolya nad deyatlnost'yu vlasti: uroki dlya Rossii [World experience of public control over governmental activity: lessons for Russia], Research and information journal "Political education", from http://www.lawinrussia.ru/mirovoi-opytobshchestvennogo-kontrolya-nad-deyatelnostyu-vlasti-uroki-dlya-rossii-0

[4] Concept of public control in Russia prepared by work group on enhancement of public control in Russia of Government Committee on coordination of activity of the Public Government, from http://granycenter.org/sites/default/files/files/page/prezentaciya_o_proekte.pdf

[5] O narodnom kontrole v SSSR [On the people's control in USSR]: The law of USSR of 30 November 1979, from http://www.zaki.ru/pagesnew.php?id=1814 .

[6] Official website of the agency of social information, from http://www.asi.org.ru/ASI3/rws_asi.nsf/va_WebResources/povysh/\$File /povysh.pdf.

[7] V.V. Buzyrev, A.O. Berezin, E.P. Kiyatkina, Regional housing construction: predicting and strategic planning. Monograph, 2009..

[8] P.G. Grabovyi, I.P. Malikova, Effektivnoe antikrizisnoe upravlenie [Effective anti-crisis management], vol. 2, pp. 66-72, 2013.

[9] A.N. Ryakhovskaya, F.G. Tagi-Zade, Tsenovaya politika $v$ zhilischnoi i kommunalnoi spherakh [Tariff and price policy in housing and communal sector], 2008..

[10] L.N. Chernyshov, P.G. Grabovoi, Rukovodstvo dlya mer po organizatsii i upravleniyu gorodskim khozyaistvom [Guidelines on measures to organize and manage municipal services], 2004.

[11] G. Wetterberg, New society, 1993.

[12] E. Deutsch, Housing finances and accumulation of housing properties: inter-generational aspect, 1999.

[13] I.A. Bashmakov, Novosti teplosnabzheniya [News of heat supply],Vol. 5 , pp. 2-11, 2005.

[14] A. Veber, Krizis evropeiskoi kultury [The crisis of European culture], Moscow: Publishing Office of Center of Humanitarian Initiatives, 2012.

[15] E.R. Romanov, V borbe za Rossiyu [In the struggle for Russia], Moscow: Golos Publisher, 1999.

[16] I.A. Bashmakov, Voprosy ekonomiki [The issues of economics], Vol. 4, pp. 136-150, 2004.

[17] E.V. Parshuto, Y.Y. Galyamov, Ekonomicheskie nauki [Economic sciences], Vol. 132, pp. 62-65, 2015.

[18] K.E. Filushina, J.A. Kolyhaeva, N.N. Minaev, O.I. Dobrynina, J.A. Merkuleva,. Mediterranean Journal of Social Sciences, vol. 6, pp. 55-62, 2015.

[19] N.N. Minaev, K.E. Filushina, J.A. Kolyhaeva, O.I. Dobrynina, Regionalnaya ekonomika: teoriya i praktika [Regional economics: theory and practice], vol. 2 (277), pp. 56-66, 2015. 